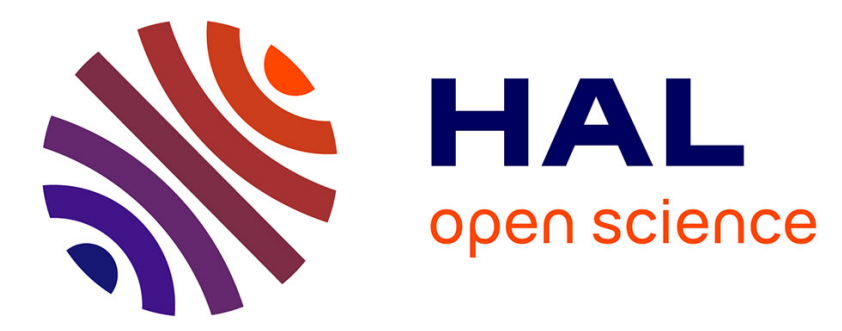

\title{
COMPLEXITY OF SCENARIOS OF FUTURE HEALTH: INTEGRATING POLICIES AND LAWS
}

Claire Lajaunie, Pierre Mazzega, Serge Morand

\section{To cite this version:}

Claire Lajaunie, Pierre Mazzega, Serge Morand. COMPLEXITY OF SCENARIOS OF FUTURE HEALTH: INTEGRATING POLICIES AND LAWS. Law, Public Policies and Complex Systems: Networks in Action. Law, 42, 2019, Law, Governance and Technology Series. hal-03099932

\section{HAL Id: hal-03099932 https://hal.science/hal-03099932}

Submitted on 6 Jan 2021

HAL is a multi-disciplinary open access archive for the deposit and dissemination of scientific research documents, whether they are published or not. The documents may come from teaching and research institutions in France or abroad, or from public or private research centers.
L'archive ouverte pluridisciplinaire HAL, est destinée au dépôt et à la diffusion de documents scientifiques de niveau recherche, publiés ou non, émanant des établissements d'enseignement et de recherche français ou étrangers, des laboratoires publics ou privés. 


\title{
Chapter 6. COMPleXity OF SCENARIOS OF FUTURE HeALTH: INTEgRating Policies AND LAWS
}

\section{Claire lajaunie, Serge Morand and Pierre Mazzega}

C. Lajaunie (corresponding author)

INSERM, CERIC, UMR DICE 7318, CNRS, Aix Marseille Univ., Univ. of Toulon, Univ. Pau \& Pays Adour, France; Affiliate Researcher SCELG Strathclyde Centre for Environmental Law \& Governance, University of Strathclyde, Glasgow, Scotland

e-mail: claire.lajaunie@inserm.fr

\section{S. Morand}

CNRS ISEM / CIRAD ASTRE, Faculty of Veterinary Technology, Kasetsart University, Bangkok, Thailand

e-mail: serge.morand@cirad.fr

P. Mazzega

UMR5563 GET Geosciences Environment Toulouse, CNRS / University of Toulouse, France; Affiliate Researcher SCELG Strathclyde Centre for Environmental Law \& Governance, University of Strathclyde, Glasgow, Scotland

e-mail: pierre.mazzegaciamp@get.omp.eu

\begin{abstract}
In Southeast Asia, regional institutions insist on the crucial role of innovative research to address sustainable development challenges. Among those challenges, the increasing human dominance of the global landscape, particularly in regard to forest cover loss is of major concern. Such dramatic habitat changes are accelerating the biodiversity loss. This reduction in biodiversity through altered landscapes due to urbanization and agricultural intensification appears linked to major epidemiological changes in human diseases with higher disease risks and the emergence of novel pathogens resulting from increased contacts between wildlife, domesticated animals and humans.

It appears necessary to investigate the multiple impacts of the intensification of the circulation along the economic corridor Thailand-Laos (linking Myanmar to Vietnam) on the evolution of infectious diseases of public health interests. Integrating the various dimensions of complexity thanks to disciplines such as ecology and environmental sciences, health sciences, policies and law, we analyse retrospectively, and comparatively infectious diseases' dynamics associated to policies, land use and biodiversity changes. The need of prospective scenarios of health that are embedded in the socioecosystems is crucial: we will thus produce scenarios of future health embodied in the One Health approach at the human-animal-environment interface and directed towards decisions-makers or communities concerned at the national or local scale
\end{abstract}

Keywords. Scenarios, health, biodiversity, complexity, governance, science policy dialogue.

\subsection{INTRODUCTION}

Even though since the United Nations Conference on the Human Environment (Stockholm, 1972), the awareness of inter-linkages between health and environment increased in the international arena, through various international conferences (United Nations Conference on Environment and 
Development, Rio 1992; World Summit on Sustainable Development, Johannesburg 2002) and a decisive involvement of the World Health Organization (WHO) in treaty-making processes, health issues were not taken into consideration as such, until recently, by the international environmental law. Few doctrinal works tempted to highlight the role that international environmental law could play in addressing health threats such as emerging diseases (Von Schirnding et al. 2002; Onzivu, 2006) but disease issues are still poorly considered through the international environmental law perspective. As a consequence, to date there is a lack of evidence-based work into the field of environmental law.

In Southeast Asia, the development of evidence-based policies is called by different agencies such as United Nations Development Program and United Nations Environment Program in Southeast Asia (cf. the Poverty-Environment Initiative in Thailand, UNDP, UNEP, Government of Thailand, 2010) or the United Nations Economic and Social Commission of Asia-Pacific (ESCAP, 2014) and at the National level in Thailand or Laos.

While focusing on regional connectivity, regional institutions such as ESCAP insist on the crucial role of innovative research to address sustainable development challenges. Among those challenges, the increasing human dominance on the global landscape, particularly in regard to forest cover loss is of major concern in the tropics (Lewis et al., 2015; Cornu et al., 2017). Such dramatic habitat changes are highlighted as a major cause of accelerated biodiversity loss (Lynam et al., 2016; Civitello et al., 2015; Wilcove et al., 2013). This reduction in biodiversity through altered landscapes due to urbanisation and agricultural intensification appears linked to major epidemiological changes in human diseases with higher disease risks and the emergence of novel pathogens resulting from increased contacts between wildlife, domesticated animals and humans (Lloyd-Smith, 2009; Brearley et al., 2013; Morand, 2017). Southeast Asia is a tropical region where both biodiversity is at high risk due to human activities and where infectious diseases are highly favoured (Coker et al., 2011; Horby et al., 2013; Gay et al., 2014; Morand et al., 2014a; Hotez et al., 2015).

It leads to different questions in the regional context of Southeast Asia: how international environmental law translated and implemented at the regional or national level can address health issues (such as diseases spread)? How regional organisations and initiatives on health or the environment or both could function together in an attempt to solve health issues? How environmental law at the regional or national level could take advantage of considering and integrating the questions related to disease ecology, biodiversity erosion, land use/land cover (LULC) change, and global changes in order to propose evidence-based policies and regulations fitting a specific local or regional context? This is the kind of issues we are addressing with the FutureHealthSEA project (2017-2021) by investigating the impacts of the intensification of the circulation along the economic corridor Thailand-Laos (linking Myanmar to Vietnam) on the evolution of infectious diseases of public health interests. Integrating ecology and environmental sciences with health sciences, policies and law, this project analyses retrospectively and comparatively infectious diseases' dynamics associated with policies, land use and biodiversity changes and combine predictive process-based scenarios and policy-driven storytelling scenarios of health incorporating disease ecology, biodiversity erosion, future land use and climate change regional impacts.

The need of prospective scenarios of health that are embedded in the social-ecological systems is a crucial issue. However, these scenarios cannot be limited to the results of phenomenological (statistical) models, although they show their interest for retrospective or comparative analyses, but they should be produced from process-based models (Section 6.2) integrating disease ecology modelling and be policy-driven (Myers et al., 2013; Mouquet et al., 2015). An excursion is proposed in Section 6.3 in the world of integrative impact assessment modelling to present some of the difficulties that arise when it comes to modelling public policies, but also the value of integrating them into the simulations as effective components of the evolution of a health-environment interaction system. This involves digitally simulating evidence-based scenarios that take into account existing or 
projected public policies and norms, and thus explore areas where public action can be expressed in the context of a science-policy dialogue (Section 6.4). Conclusions are drawn in Section 6.5.

\subsection{The Need of Process-Based Prospective Scenarios}

Previous projects ${ }^{61}$ have shown that biodiversity and environmental changes, notably land use changes at regional to local scales are factors of health risks and of emergence of zoonotic diseases. They highlighted the fact that biodiversity is a source of pathogens diversity as well as a source of biological diversity as well and even cultural diversity (Morand et al., 2014b; Morand and Lajaunie, 2017). They confirmed the importance of the spatio-temporal dynamics of the land use land cover in determining the diversity of wildlife and their parasites, in particular through the use of network analyses (Bordes et al., 2016; Pilosof et al., 2015) with implications for human risk of zoonotic diseases. Regarding health, the insights gained from those projects underlined the necessity to understand the various dynamics at stake and to develop scenarios of future health embodied in the One Health approach at the human-animal-environment interface.

The One Health approach to manage the risks presented by animal diseases and zoonoses at the animal human-ecosystem interface started spreading into international environmental agreements related to biodiversity, acknowledging as such the role of biodiversity in addressing well-being and health issues (Lajaunie and Mazzega, 2016). This acknowledgment leads to the creation of the Intergovernmental Platform on Biodiversity and Ecosystem Services (IPBES) modelled on the Intergovernmental Panel on Climate Change (IPCC) to be an efficient science-policy interface mechanism able to improve policy-relevant information about the state, trends and outlooks of human-environment interactions with a focus on the impacts of ecosystems change on human well-being. The Strategic Plan for Biodiversity 2011-2020 ${ }^{62}$ integrates this aspect by defining strategic goals and targets (Aichi biodiversity targets ${ }^{63}$ ) in order to halt the loss of biodiversity and thus contribute to human well-being. These Aichi targets, as well as the IPBES assessments and the One Health approach, implies a translation at the national level of those international strategies and Thailand is very committed into the implementation of these strategies and tends to have a leadership role at the regional level on these aspects.

In the context of climate change, the IPCC build scenarios and storylines describing different options of the evolution of the world through the 21 st century by taking into account socio-economic factors. Thus, the scenarios proposed by the IPCC, called Special Reports on Emission Scenarios ${ }^{64}$, are based on factors such as the global population, economic development (expressed in annual Gross Domestic Product) or measure of equity (per capita income ratio). It is striking to see that the methodology of scenarios developed by the IPBES, which main goal is to strengthen the science-policy interface, is distinguishing between four different types of scenarios, supposed to play "important roles in relation to the major phases of the policy cycle" ${ }^{\prime 65}$. Nevertheless, the IPBES does not seem to suggest the integration of policies and law as factors involved in the dynamic of change of biodiversity and of modification of the environment at large.

In addition, the Executive Secretary of the Convention on biodiversity in a note to provide its Subsidiary Body on Scientific Technical and Technological Advice (SBSTTA) relevant information

\footnotetext{
${ }^{61}$ ANR Project BiodivHealthSEA "Local impacts and perceptions of global changes: Biodiversity and Health in Southeast Asia" (2012-2016) and ANR Project Ceropath "Community Ecology of Rodents and their Pathogens in Southeast Asia" (2007-2011).

${ }^{62}$ https://www.cbd.int/sp/ Accessed 25 Feb 2018

${ }^{63}$ https://www.cbd.int/sp/targets/ Accessed 25 Feb 2018

${ }^{64}$ See e. g. https://www.ipcc.ch/pdf/special-reports/emissions_scenarios.pdf Accessed 25 Feb 2018

${ }^{65}$ See https://www.ipbes.net/scenarios Accessed 25 Feb 2018
} 
on scenarios for the 2050 Vision for Biodiversity underlined the fact that "quantitative models that incorporate feedback regarding biodiversity change on ecosystem services and human well-being have not been incorporated into comprehensive scenarios" (SBSTTA, 2017 §20). Among those feedbacks we must consider the spillover effects of policies and law (for instance on land use, agricultural policy, protected areas, forest logging).

However, few studies have allowed policy makers to anticipate the full health implications of their decisions, which implies that research effort should explore the multiple health outcomes of ecosystem alteration, taking into account the socio-ecological dynamic changes. Investigating multiple diseases of public health importance may then generate useful insights for policy (see Box 6.1). The emphasis should then be put on policy-driven research. Most of studies that put their scientific efforts in biodiversity conservation or ecosystem services tend to proceed from basic research to policy application, forgetting the advice of Myers et al. (2013) that a basic reversal of approach from policydriven application to basic research with the objective of producing scenarios will participate to the increasing value of scientific results to society.

\section{Box 6.1 Some Emerging Infectious Diseases related to the Environment}

Biological diversity and the complexity of interactions are also expressed by the large number of emerging or re-emerging infectious diseases (here in South-East Asia) linked to environmental dynamics through mechanisms and via specific paths. Four criteria guided our selection of diseases to be studied in the FutureHealthSEA project: a) to address diseases with a significant impact on public health; b) to select diseases allowing to explore the relative importance of environmental change, the role of domestic animals, wildlife and various vector types; (c) the availability of data on the entities and processes involved; d) to allow a parsimonious use of scientific curiosities (the resources allocated to the project being limited). The diseases selected are the following:

Leptospirosis. The main types of leptospiroses considered (based on their genotyping and serotyping) differ in the importance of the factors of LULC change (e.g. through the intensification of agriculture and livestock farming) and environmental changes (water and soil), and dependence to survive outside the hosts, whether humans, livestock or wildlife, in their dynamics.

Scrub Typhus. Forest cover, which increases with altitude (very few forests in the plains) is one main determinant of the epidemiology of the scrub typhus (our terrain in Nan Province ranges between $100 \mathrm{~m}$ and $1700 \mathrm{~m}$ ) through the changes of forest types, the diversity of the chigger mites' vectors and reservoirs, and the rodents hosts for chiggers development (Chaisiri et al., 2016, 2017). The spatial diffusion of scrub typhus is limited by the low dispersion of bacteria (trans-ovarian transmission from one mite generation to the next, no re-infection) but can be enhanced by dispersion of the mammalian hosts of the chiggers (Morand et al., 2018).

Dengue. Dengue affects only humans preferentially in peri-urban areas and its epidemiology is well described in Vietnam (van Panhuis et al., 2015). Its vectors, Aedes aegypti and Aedes albopictus, show resistance to insecticides. The approach we develop could be transposable to other vector-borne diseases (babesiosis, bartonellosis, zika, chikungunya, Japanese encephalitis). We consider two types of transmission, simple vector-borne (mosquitoes/humans such as dengue, chick) and complex vector borne with reservoirs (ticks or fleas or mosquitoes / mammals / humans such as babesia, bartonella, Japanese encephalitis). We also investigate whether local development scenarios could provide the conditions for the re-emergence of malaria (via Anopheles mosquitoes) (Overgaard et al., 2015).

Melioidosis. Although it is a real threat, there are no systematic recording of melioidosis (Burkholderia pseudomallei) due to a telluric bacteria (Ribolzi et al., 2016), for which the modes of contamination are little known (Buisson et al., 2015).

In the scenarios, multi-level public policies will be considered via the impacts they are likely to have on land use-land cover, habitats or on health (e.g. prophylactic measures). We use various types of assessments (such as Strategic Environmental Assessment (World Bank 2009; Li et al., 2012) or Landscape Ecological Assessment (Mortberg et al., 2007; Lee et Ho, 2012), different public policy 
appraisals (UNDP Thailand, 2014) or case studies (UNDP Thailand, 2014; OECD, 2014) to help build scenarios. We aim at the production of indicators for decision makers from local to regional (ASEAN) level, along with their uncertainty and caveats about the limitations of their use, including ethical, and prospective proposals of strategic directions for evidence-based policies linked with the possible mitigation of outbreaks and spread of infectious diseases in the ASEAN economic corridor.

\subsection{Integrating Policies and Regulations in Environment \& Health MODELS}

Technically, the future health scenarios we are developing are based on formal modelling and computer simulations. In recent years, impact assessment modelling has shown the interest (and possibilities) of integrating a variety of multi-scale environmental processes (Hamilton et al., 2015; Milat et al., 2015). Our purpose here is not to present this approach applied to the emergence of infectious diseases related to environmental changes, but to discuss the importance of integrating public policy representations and legal norms into simulation platforms, as integral components of social-ecological systems with direct impacts, though entangled through a myriad of processes, on the evolution of these systems.

\subsubsection{On Policy Modelling}

The term "policy modelling" covers a diversity of domains like social computing, policy analysis, visualisation (in policy modelling), citizen engagement, public opinion mining and sentiment analysis, visual analytics (including analytical reasoning) and linked data in open government information, trust in governance, public service aggregation, mash-ups and orchestration, just to mention a few items identified in the CROSSROAD (2010) project. In the present context, we focus on the development of formal representations of the entities and processes involved in a given public policy ${ }^{66}$, and the use of these representations in computers in order to simulate in silico the evolution of the state of these entities, eventually in interaction with other policy-driven, socially driven or environmental processes. A policy is by itself a complex system involving actors, material (natural resources, infrastructures, financial resources, etc.) and cognitive resources (data, knowledge, norms), which state changes under process' and actors' actions. A generic framework to represent a large set of such policies having potential impacts on social-ecological systems is described in Chap. 4 of this volume (Sibertin-Blanc et al., 2018). Its use makes it possible to clarify the concepts used in an interdisciplinary project, to share knowledge (especially between tenants from different disciplines) and to base the work on an abstract system of consensual knowledge representations. For example, the notion of "human well-being" may be considered as an indicator aggregating information on the state of variables related to the health of a population of (human) individuals but could equally well include information concerning the quality of the environment of this population (animal health, ecosystem health, ...).

Several difficulties arise when it comes to modelling policies and their impacts, some of which are:

- A public policy simultaneously modifies the states of several actors and resources;

- The state of a resource is likely to modify the conditions of the implementation of a policy ${ }^{67}$;

- The effect of a policy depends on its social acceptability and on the degree of compliance with which it is followed by various social groups;

\footnotetext{
${ }^{66}$ For simplicity, we will consider here that the term "policy" also includes the class of norms and legal regulations. This shortcut is justified by the equally normative nature of public policies whose action aims to reach a different state of affairs than the current state.

${ }^{67}$ A change of state of a resource can also lead to the design and implementation of a targeted policy.
} 
- Each actor (individual or collective) interprets a policy (assuming he is aware of its existence and requirements) and integrates it in his own way into a behavioural strategy.

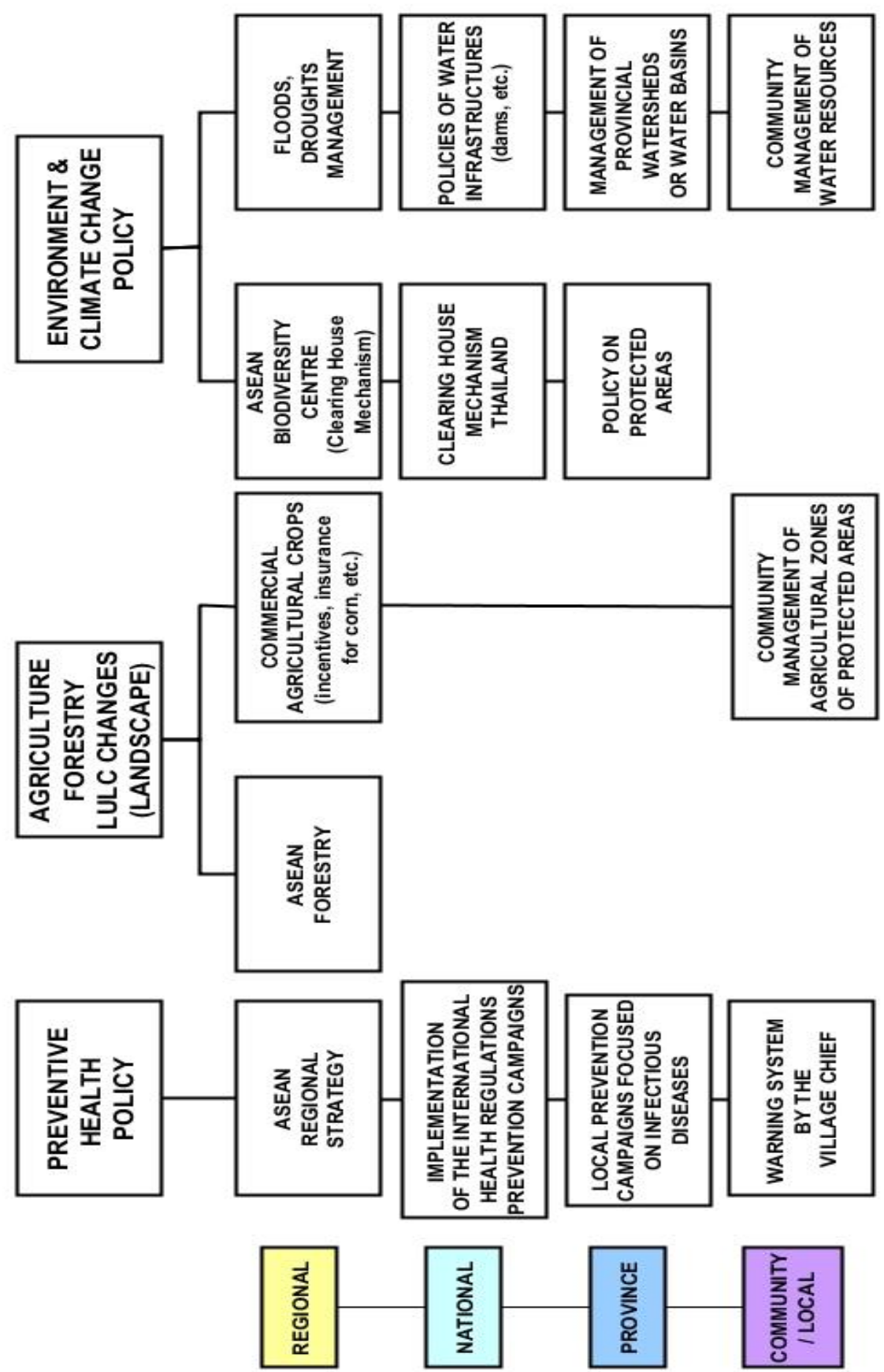

Fig. 6.1 Main public policies integrated into the modelling of the emergence of infectious diseases (see Box 6.1) in the province of Nan (Thailand). The left column shows the decision-making levels of their implementation

The identification of each process that a public policy solicits, of each activity and actor who carries it out, and the representation of how the state of the resources are modified, are at the heart of impact modelling $^{68}$. A parsimony principle guides the modelling: processes with little impact or impact on

\footnotetext{
${ }^{68}$ The processes themselves can be modified: the impact of deforestation on the water cycle - on runoff, recharge of groundwater, etc. - or soil depletion is a known example.
} 
state variables of no interest for the issue considered are set aside ${ }^{69}$. The main areas of public policy that we take into account in the study of the emergence and epidemiology of the selected infectious diseases are presented in Figure 6.1.

\subsubsection{Entangled Process Dynamics}

Regardless of their respective decision-making levels, all public policies and regulations and norms implemented in a given territory are supposed to act, simultaneously, on the behaviour of the actors, on the resources, and sometimes exert control over some processes (e. g. environmental services). The state of the various resources - biodiversity, soil, forests, water, air ... - conditions in return the actions and possible behaviours of the actors, as well as the overall context of application of the policies and norms. The interactions take place in a continuous flow. Causality is diffuse, with changing intensities and orientations, and through evolving actors and resources networks.

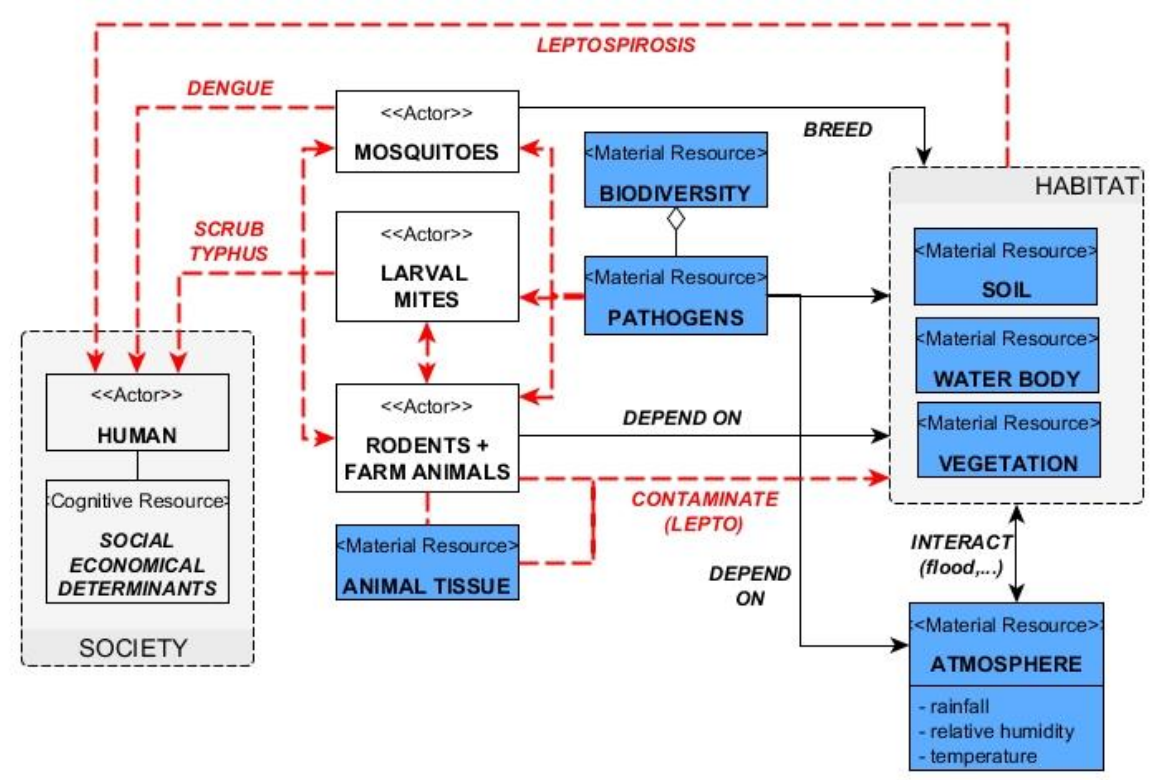

Fig 6.2 Stylisation of the main interactions between resources and actors involved in the emergence and epidemiology of selected infectious diseases (disease-related links are in dashed lines).

Figure 6.2 is a highly stylised representation of interactions between resources and actors involved in the emergence and epidemiology of infectious diseases that we consider. At this level of abstraction, the labels of the entities or processes must be considered as classes whose main elements are, in a second phase of the modelling process, identified and represented in relation to the other entities and processes of the modelled system. For example, in this specific context the ecological concept of habitat brings together soils, bodies of water and vegetation (each of these entities being endowed with relevant state variables and functions capable of modifying the state variables of other entities). The interactions between the atmosphere and habitats or pathogens are also multiple (effects of precipitation, air humidity and temperature, for example). The complexity of this schema can be increased and its conceptual accuracy improved progressively for example by taking into account human settlements, which are important for synanthropic species such as some species of mosquitoes (Aedes), ticks (dogs, cattle), or rodents (Rattus). Larval mites are the reservoirs and vectors for Orientia tsutsugamushi while rodents are not, but they are the hosts for larval chiggers' development. Chiggers are linked with habitat as they need soil and vegetation to mature, reproduce (and to lay eggs for a new generation of infected / non infected larval mites). Some pathogens (Leptospira,

\footnotetext{
${ }^{69}$ From the point of view of modelling, such choices are guided by sensitivity analyses (see below).
} 
Bulkholderia, some viruses) are directly in contact with the environment and are dependent upon its quality ( $\mathrm{pH}$, turbidity and others), some others are in contact indirectly with the environment through their vectors (Bartonella, Orientia tsutsugamushi, Babesia).

An effective way to simulate the interactions between various public policies is to consider their impacts on resources whose changing state is "exposed" to the activity of the actors. If the empirical observation and formal representation of the direct interactions between actors often present insuperable difficulties (e. g. interactions between groups of rational strategic agents), the mediation of these interactions by the evolutionary state of the resources makes it possible to reproduce empirical dynamics.

Thus Figures 6.1 and 6.2 are to be reconciled by connecting each public policy with each resource (characterised by its nature, if any geographical extension, etc.) it impacts in a potential or proven manner. For example, prophylaxis measures impact pathogens (considered in the meta-class of material resources for the purposes of this modelling of future health scenarios) and people's health. Incentives for the development of cash crops have observable effects (through LULC high resolution maps, landscape changes analysis, field surveys) on the forest, on the water cycle, therefore on habitats and biodiversity, but also on rodents, that in turn are candidate vectors of pathogens. Climate change has effects - direct or indirect - on just about every component and process of social-ecological systems.

It is important to emphasise what may seem like a paradox. A public policy is conceived ex ante according to a causal schema that wants its implementation to have well identified or even quantifiable effects. Of course, collateral, unexpected effects can also occur (especially because of the inventiveness of human actors). However, particularly in those policies and norms implementation whose pathways are interpenetrated by environmental dynamics (involving biological, biogeochemical or physical processes) it is almost illusory to claim to attribute to each of the measures the share of changes that it has induced on the trajectory of evolution of the social-ecological systems empirically observed. A whole range of predictability of the evolution of the states of the actors and resources mixes (from quasi-certain predictions to the complete uncertainty for example concerning some collective decision-making) as well as effects delayed in time or in space, and effects cascading in a range of scales. Nevertheless, this observation, far from making the integrated impact assessment models obsolete, makes it indispensable (irreplaceable) through the simulation of process-based scenarios.

\subsubsection{Integrated Impact Assessment Scenarios}

The ability of the integrative model to represent with acceptable realism the dynamics of the socialecological system is evaluated in comparison with a set of heterogeneous data related to the state variables of the model entities. In silico simulation of the interaction of processes and activities of virtual actors must reproduce as much as possible the past observations and data. The diversity of data types (on LULC changes, biodiversity, epidemiology, demography, economic data, stakeholder strategies, etc.) is essential to ensure relevant representativeness of the empirical information and thus verify the coherence of the integrative model ${ }^{70}$. The sensitivity analysis, which consists in testing the impact of different configurations of the integrative model on the observable variables, allows calibrating certain parameters, adjusting the model procedures and, if necessary, simplifying its representations. At the end of this phase, the model faithfully reproduces the trajectory of the social-

\footnotetext{
${ }^{70}$ Note, however, that this procedure cannot guarantee that another system of formal representations could pass this comparison test with the empirical data in just the same way. We will not develop this point, which raises questions about the ethics of modelling that we address elsewhere (see Mazzega, 2018 submitted).
} 
ecological system as it has been observed and leads to an exhaustive description of the state of its variables considered as an initial system state from which the prospective scenarios will be simulated. The business as usual scenario (BAU, see Figure 6.3A) assumes that none of the conditions that governed the past evolution of the system will change in the future: the continuation of the simulation over the period of time of interest produces a description of the evolution of the system (and useful indicators) that will be used as a reference for comparison with other trajectories. Other scenarios can then be designed and simulated: modification of a compliance rate of the actors with the existing policies and regulations (condition set $C 1$ and trajectory \#T1 of Fig. 6.3A), implementation of a new policy of health or biodiversity conservation (condition set $C 2$ and trajectory \#T2 of Fig. 6.3A), etc., all other things being kept unchanged in the model simulation.

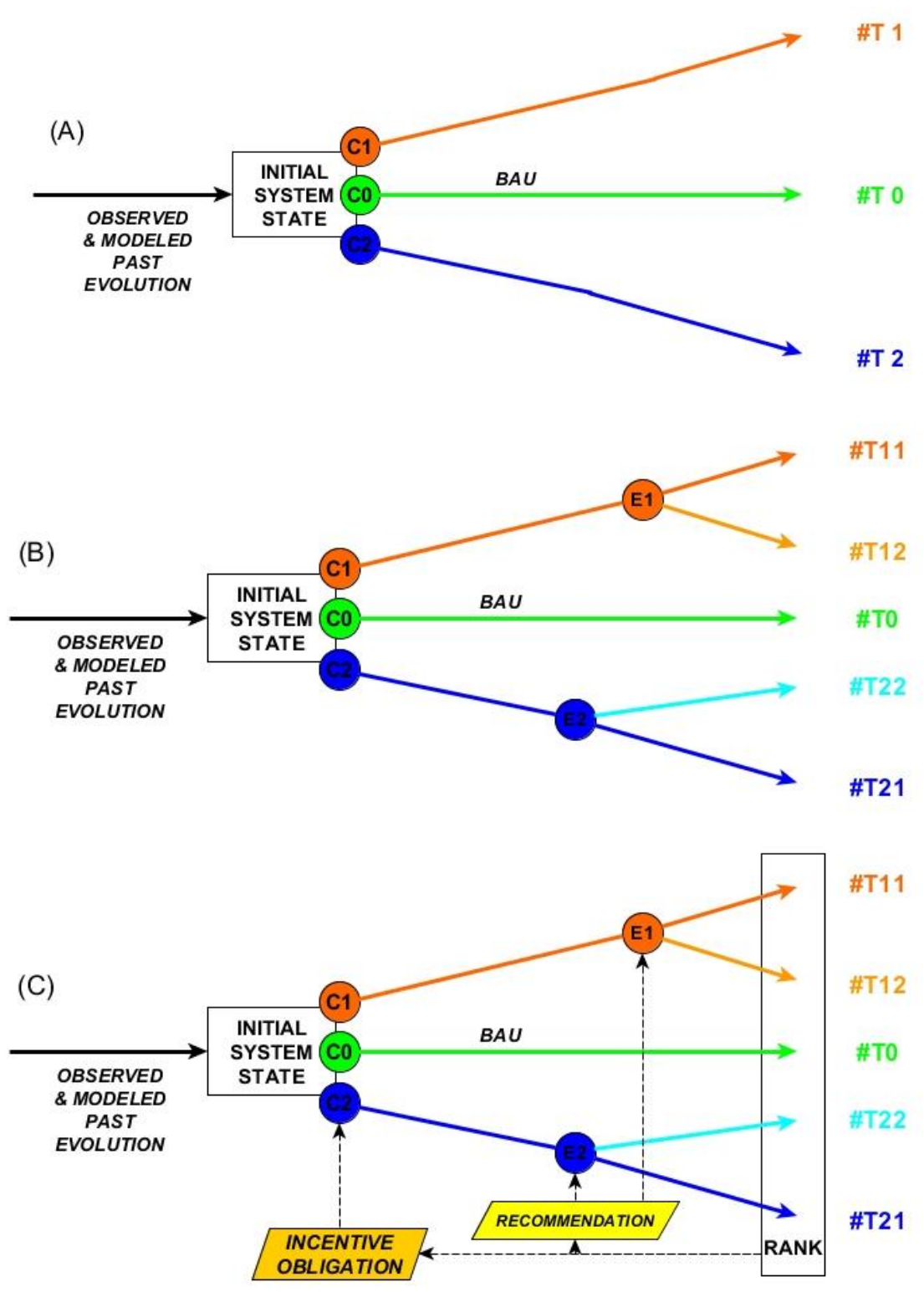

Fig. 6.3 Schemes of progressive constructions of scenarios (conditions $C j$, event $E j$, trajectory $\# T j k$ ) and their possible use for the implementation of incentives or obligations (see text)

Many social and political interactions do not follow one another in a simply mechanistic way. Note however that ecosystem or biological dynamics present, from the point of view of modelling, behaviours just as little predictable, even poorly understood - like the biodiversity tipping points (Leadley et al., 2010). A relatively satisfactory approach to these phenomena is to consider as many 
potential events in time (these are E1 and E2 in Figure 6.3B), and to make assumptions about the likely results of their occurrence. The way in which these assumptions are likely to modify the conditions of evolution of the subsequent trajectories are taken into account as so many branching subscenarios. The combinatorial of the scenarios' condition sets and events thus leads to diversifying the possible evolutions explored by simulation.

The scenarios are designed to provide analysis elements to specific communities - policy and decision makers, citizens or local communities, scientists - based on scientific knowledge and data that can be mobilized. By considering all intermediate and final states of modelled actors and resources, a likely trajectory of evolution can be perceived as the more desirable than another one, which leads to a hierarchical ranking of scenarios, from the more to the less desirable ones. Specifically, a desirable scenario may involve the implementation of incentives or obligations, or the consideration of specific policy recommendations if a given event occurs (Fig. 6.3C). However, this cycle can only be exploited if the conditions for a science-policy dialogue are well established, and this in the long term.

\subsection{SCIENCE-POLICY Dialogue FOR INFORMEd POLICIES AND LAW}

First, the results of the CERoPath project advocate focusing on diseases of public health importance for the area studied in order to facilitate a science-policy dialogue. This has been started with the BiodivHealthSEA project (2012-2016) for studies implemented at a local scale (village or district) by investigating zoonotic diseases or antimicrobial resistance at human - livestock - wildlife interface in Northern Thailand and Laos (Ribas et al., 2017, Olaitan et al., 2015, Olaitan et al., 2016). In 2006, the Nan Province was affected by a flood event and 1,400 cases of leptospirosis were reported after the peak of the flooding, which led the government to set up a prevention campaign. The extensive survey of Leptospira infection in rodents gathered in 2008 and 2009 in the CERoPath project was compared to the human incidence of the disease from 2003 to 2012 gathered by the BiodivHealthSEA project in 168 villages with the collaboration of two district hospitals. Using an ad hoc developed land-use cover model, humans and rodents were observed as not infected in the same environment. Interestingly, there was a strong effect of public health campaigns conducted after the dramatic flood event of 2006. This study confirmed the role of the environment and particularly the land use in the transmission of bacteria, emphasised by the effects of the provincial public health campaigns on the epidemiological pattern of incidence, and questioned the role of wildlife as reservoirs (Della Rossa et al., 2016). Locally, health and environmental policies are highlighted as a key component of the epidemiological landscape. Similar ongoing studies concern the epidemiology of scrub typhus (Chaisiri, 2016).

A recent PhD study (Jaruwan Viroj, lecturer at Maha Sarakham University, enrolled in Montpellier University) constitutes another pilot study for future health scenarios. The epidemiology of leptospirosis and the public health policy are investigated by collecting the leptospirosis incidence data at the individual level (village) over 2004-2014 from the Department of Disease Control, the land use and socio-economic data (at the level of the village) from the Land Development Department, the Department of Public Health, and information on livestock and poultry than could carry Leptospira bacteria from the Department of Livestock Development.

Intensive survey with questionnaires and interviews of former infected and non-infected people (600 persons) has already been conducted, in order to obtain their perceptions and knowledge of the disease, its epidemiology, its control, and the potential roles of animal reservoirs. A second survey with questionnaires and interviews of health volunteers, public health officers, and community leaders (700 persons) has been given about for their perceptions on the strengths and weaknesses of leptospirosis control. All these data are already gathered and integrated in a linked geo-referenced database to be investigated statistically. The spatio-temporal epidemiology will be discussed in the 
light of a policy analysis of the leptospirosis surveillance and prevention scheme of Public Health (at both national and provincial levels).

This work contributes to the development of evidence-based policies and law. International environmental law (IEL) developed under the influence of ecology and both disciplines started to coevolve since the 1970s (Turgut, 2008). One distinctive feature of IEL is that it promotes cooperation among States to realise common gains (Bodansky, 2010): there is an underlying notion of "general interest" as in public law, and this principle guides our research as it induces regional and transboundary cooperation, transposition of interesting solutions, common strategies. It also calls for a fluid interdisciplinarity due to the complex natures of social-ecological systems. Similarly, we think disease ecology, which studies host-pathogen interactions within the context of their environment and evolution, could play a decisive role for bridging public health and conservation policies. Furthermore, local participatory initiatives, community-based management of natural resources (Salam et al., 2006), specific customary law or regulations (on health, agriculture, forestry, biodiversity, water and soil) constitute case studies that can give insights for legal solutions and for evidence-based policies (Koon et al., 2012) that should be taken into account and up-scaled at the national level: we are studying some specific cases that could help to specify, confirm or modify national strategies and plans.

We consider that complex interplay of multiple contemporaneous environmental changes (e. g. LULC, climate change or exchanges intensification) on multiple dimensions of health need to be better assessed in order to gain utilities for public health policy, biodiversity conservation, and practices. The scenarios (Alcamo and Henrichs, 2008; Biggs et al., 2007) we will produce are not "predictive" because of the multiplicity and the complexity of interactions associated to the contingency of political decisions but "prospective". As such they are directed towards decision makers (Alcamo and Henrichs, 2008; Spierenburg, 2012) or communities concerned at the national or local scale.

The main goal of the ongoing FutureHealthSEA project is thus to produce results that are reflecting local concerns, responding to the need of an evidence-based approach championed by national law such the new Thai rules and procedures for the Health Impact Assessment of Public Policies (National Health Commission Office; NHCO, 2016). The United Nations Environment Programme is also calling for the development of evidence-based decision-making to reach the Sustainable Development Goals by 2030 (UNEP, 2015). Indeed, we are aiming at developing a grounded research in line with the current considerations at the local, national or regional level and to build a dialogue between scientists and policy-makers to identify issues related to the interactions "biodiversity-infectious diseases" notably in order to facilitate the monitoring and assessment of public policies.

\subsection{CONCLUSION}

Assuming that changes in the environment and in the biodiversity whether they result from international or national policies or community actions have an impact on the evolution of health risks, the project proposes to prospective scenarios embodied in the One Health approach at the humananimal-environment interface to anticipate the influence of those changes. The originality of the project is to integrate law and policies regarding the environment and health as integral part of the various factors of changes. It requires to gather various types of data and to take different approaches into consideration. Addressing the different challenges, the project implies is rendered possible thanks to the implication of a variety of local and regional academic and institutional partners convinced by the interest of such an approach and willing to test it in concrete situations at the district, provincial or national level for instance. 
Acknowledgements. This work is a contribution to the ANR Project FutureHealthSEA ( $n^{\circ}$ ANR-17CE35-0003-02) "Predictive scenarios of health in Southeast Asia: linking land use and climate changes to infectious diseases" (PIs: S. Morand and C. Lajaunie). The Ecology and Environment Institute of the National Centre for Scientific Research (InEE CNRS, France) supports the International Multidisciplinary Thematic Network "Biodiversity, Health and Societies in Southeast Asia," Thailand (PI: S. Morand, CNRS / CIRAD) to which this study also contributes.

\section{REFERENCES}

Alcamo J, Henrichs T (2008) Towards guidelines for environmental scenario analysis. In: Alcamo J (ed) Environmental Futures: The Practice of Environmental Scenarios. Elsevier, Amsterdam, p 1351

Biggs R, Raudsepp-Hearne C, Atkinson-Palombo C, Bohensky E, Boyd E, Cundill G, Fox H, Ingram S, Kok K, Spehar S, Tengö M, Timmer D, Zurek M (2007) Linking futures across scales: a dialog on multiscale scenarios. Ecology \& Society 12:17. Available from http://www.ecologyandsociety.org/vol12/iss1/art17/ Accessed 25 Feb 2018

Bodansky D (2010) The art and craft of international environmental law. Harvard University Press, Cambridge

Bordes F, Caron A, Blasdell K, de Garine Wichatitsky M, Morand S (2016) Forecasting potential emergence of zoonotic diseases in South-East Asia: network analysis identifies key rodent hosts. Journal of Applied Ecology 54(3):691-700. DOI: 10.1111/1365-2664.12804

Brearley G, Rhodes J, Bradley A, Baxter G, Seabrook L, Lunney D, Liu Y, McAlpine C (2013) Wildlife disease prevalence in human-modified landscapes. Biological Reviews of the Cambridge Philosophical Society 88:427-442. doi: 10.1111/brv.12009

Buisson Y, Rattanavong S, Keoluangkhot et al. (2015) Melioidosis in Laos. In: Morand S, Dujardin JP, Lefait-Rollin R, Apiwathnasorn C (eds) Socio-ecological dimensions of Infectious Diseases in Southeast Asia. Springer Singapore, p 89-104

Chaisiri K, Cosson J-F, Morand S (2017) Infection of rodents by Orientia tsutsugamushi, the agent of scrub typhus in relation to land use in Thailand. Tropical Medicine and Infectious Disease 2(4):53. doi:10.3390/tropicalmed2040053

Chaisiri K, Stekolnikov AA, Makepeace BL, Morand S (2016) A revised checklist of chigger mites (Acari: Trombiculidae) from Thailand, with the description of three new species. Journal of Medical Entomology 53(2):321-42. DOI: 10.1093/jme/tjv244

Chaisiri K, McGarry JW, Morand S, Makepeace BL (2015) Symbiosis in an overlooked microcosm: A systematic review of the bacterial flora of mites. Parasitology 142(9):1152-62. doi: 10.1017/S0031182015000530

Civitello DJ, Cohen J, Fatima H, Halstead NT, McMahon TA, Ortega CN, Sauer EL, Young S, Rohr JR (2015) Biodiversity inhibits parasites: Broad evidence for the dilution effect. Proceedings of the National Academy of Sciences 112(28):8667-8671. https://doi.org/10.1073/pnas.1506279112

Coker RJ, Hunter BM, Rudge JW, Liverani M, Hanvoravongchai P (2011) Emerging infectious diseases in Southeast Asia: regional challenges to control. Lancet 377(9765):599-609. doi: 10.1016/S0140-6736(10)62004-1

Cornu J-F, Lajaunie C, Laborde H, Morand S (2017) Landscape changes and policies for biodiversity and environment conservation in Southeast Asia. In: Morand S, Satrawaha R, Lajaunie C (eds) Biodiversity Conservation in Southeast Asia: Challenges in a Changing Environment. Routledge EarthScan, London, p 49-66 
CROSSROAD (2010) A participative roadmap for ICT research in electronic governance and policy modeling - State of the art analysis. D1.2, FP7-ICT-2009-4 SA Project

Della Rossa P, Tantrakarnapa K., Sutdan, D, Cosson, JF, Chaisiri K, Tran A, Suputtamongkol S, Binot A, Lajaunie C, Morand S (2016) Environmental factors and public health policy associated with human and rodent infection by leptospirosis: a land-cover based study in Nan Province (Thailand). Epidemiology \& Infection 144(7):1550-1562. https://doi.org/10.1017/S0950268815002903

ESCAP (2014) ESCAP Annual Report 2014. United Nations Economic and Social Commission for Asia and the Pacific, Thailand, 65 p. Available at http://www.unescap.org/resources/escap-annualreport-2014 Accessed 25 Feb 2018

Gay N, Olival KJ, Bumrungsri S, Siriaroonrat B, Bourgarel M, Morand S (2014) Parasite and viral species richness of Southeast Asian bats: fragmentation of area distribution matters. Int J Parasitol Parasites Wildl 3(2):161-70. doi: 10.1016/j.ijppaw.2014.06.003

Hamilton SH, ElSawah S, Guillaume JHA, Jakeman AJ, Pierce SA (2015) Integrated assessment and modelling: overview and synthesis of salient dimensions. Environmental Modelling \& Software 64:215-229. https://doi.org/10.1016/j.envsoft.2014.12.005

Horby PW, Pfeiffer D, Oshitani H (2013) Prospects for Emerging infections in East and Southeast Asia 10 Years after severe acute respiratory syndrome. Emerging Infectious Diseases 19(6):853860. doi:10.3201/eid1906.121783

Hotez PJ, Bottazzi ME, Strych U, Chang LY, Lim YAL, Goodenow MM, AbuBakar S (2015) Neglected tropical diseases among the Association of Southeast Asian Nations (ASEAN): Overview and update. PloS Neglected Tropical Diseases 9: e0003575

Koon AD, Nambiar D, Rao KD (2012) Embedding of research into decision-making processes, Background paper commissioned by the Alliance for Health Policy and Systems Research to develop the WHO Health Systems Research Strategy, Public Health Foundation of India. Available on $\quad$ http://www.who.int/alliance-hpsr/alliancehpsr backgroundpaperembeddingresearch.pdf Accessed 25 Feb 2018

Lajaunie C, Mazzega P (2016) One Health and biodiversity conventions. The emergence of health issues in biodiversity conventions. IUCN Acad. of Environmental Law eJournal 7:105-121. Available on www.iucnael.org/en/documents/1324-iucn-ejournal-issue-7 Accessed 25 Feb 2018

Leadley P., Pereira H. M., Alkemade R., Fernandez-Manjarres J. F., Proenca V., Scharlemann J. P. W. and M. J. Walpole (2010) Biodiversity scenarios: projections of $21^{\text {st }}$ century change in biodiversity and associated ecosystem services. Technical Series no. 50, Secretariat of the Convention on Biological Diversity, Montreal, 132 pp.

Lee DW, Oh KS (2012) A landscape ecological management system for sustainable urban development. APCBEE Procedia 1: 375-380. https://doi.org/10.1016/j.apcbee.2012.03.062

Lewis SL, Edwards D, Galbraith D (2015) Increasing human dominance of tropical forests. Science 349(6250):827-32. doi: 10.1126/science.aaa9932

Li W, Liu Y, Yang Z (2012) Preliminary strategic environmental assessment of the great western development strategy: safeguarding ecological security for a new western China. Environmental Management 49(2):483-501. doi: 10.1007/s00267-011-9794-1

Lloyd-Smith JO, George D, Pepin KM, Pitzer VE, Pulliam JR, Dobson AP, Hudson PJ, Grenfell BT (2009) Epidemic dynamics at the human-animal interface. Science 326(5958):1362-7. doi: 10.1126/science. 1177345

Lynam AJ, Porter L, Campos Arceiz A (2016) The challenge of conservation in changing tropical Southeast Asia. Conservation Biology 30:931-932

Mazzega P (2018) On the ethics of biodiversity models, forecasts and scenarios. Asian Bioethics Review, submitted. 
Milat AJ, Bauman AE, Redman S (2015) A narrative review of research impact assessment models and methods. Health Research Policy and Systems 13:18 . DOI 10.1186/s12961-015-0003-1

Morand S (2018) Biodiversity and disease transmission. In: Hurst CJ (ed) The Connections between Ecology and Infectious Disease, Advances in Environmental Microbiology. Springer, Berlin, accepted for publication.

Morand S, Lajaunie C (2018) Biodiversity and health. ISTE Press / Elsevier, London / Oxford

Morand S, Blasdell K, Bordes F, Buchy P, Carcy B, Chaisiri K, Chaval Y, Claude J, Cosson JF, Desquesnes M, Jittapalapong S, Jiyipong T, Karnchanabanthoen A, Pornpan P, Rolain JM, Tran A (2018) Changing landscapes of Southeast Asia and rodent-borne diseases: decreased diversity but increased transmission risks. Ecological Applications, in revision

Morand S, Jittapalapong S, Supputamongkol Y, Abdullah MT, Huan TB (2014a) Infectious diseases and their outbreaks in Asia-Pacific: biodiversity and its regulation loss matter. PLoS One 9(2): e90032.

Morand S, Owers K, Bordes S (2014b) Biodiversity and emerging zoonoses. In: Yamada A, Kahn LH, Kaplan B, Monath ThP, Woodall J, Conti L (eds) Confronting Emerging Zoonoses: The One Health Paradigm. Springer, Japan, p 27-41

Mortberg UM, Balfors B, Knol WC (2007) Landscape ecological assessment: a tool for integrating biodiversity issues in strategic environmental assessment and planning. Journal of Environmental Management 82(4): 457-70. https://doi.org/10.1016/j.jenvman.2006.01.005

Mouquet N, Lagadeuc Y, Devictor V, Doyen L, Duputie A, Eveillard D, Faure D, Garnier E, Gimenez O, Huneman P, Jabot F, Jarne P, Joly D, Julliard R, Kefi S, Kergoat GJ, Lavorel S, Le Gall L, Meslin L, Morand S, Morin X, Morlon H, Pinay G, Pradel R, Schurr FM, Thuiller W, Loreau M (2015) Predictive ecology in a changing world. Journal Applied Ecology 52(5):1293-1310. DOI: $10.1111 / 1365-2664.12482$

Myers SS, Gaffikin L, Golden CD, Ostfeld RS, Redford KH, Ricketts TH, Turner WR, Osofsky SA (2013) Human health impacts of ecosystem alteration. Proceedings of the National Academy of Sciences 110 (47):18753-18760. https://doi.org/10.1073/pnas.1218656110

NHCO (2016) Thailand's rules and procedures for the health impact assessment of public policies. National Health Commission Office, Bangkok, Thailand, p.77. Available from https://en.nationalhealth.or.th/wp-content/uploads/2017/11/HIA2_ENG-final.pdf Accessed $25 \mathrm{Feb}$ 2018

OECD (2014) Towards green growth in Southeast Asia. Solutions for policy makers. Organisation for Economic Co-operation and Development, Paris, 28 p. Available on https://www.oecd.org/dac/environment-development/Final SE Asia Brochure low res.pdf Accessed $25 \mathrm{Feb} 2018$

Olaitan A, Thongmalayvong B, Akkhavong K, Somphavong S, Paboriboune P, Khounsy S, Morand S, Rolain J-M (2015) Clonal transmission of a colistin-resistant Escherichia coli from a domesticated pig to human in Laos. Journal of Antimicrobial Chemotherapy 70(12):3402-4. doi: $10.1093 / \mathrm{jac} / \mathrm{dkv} 252$

Olaitan AO, Chabou S, Okdah L, Morand S, Rolain JM (2016) Dissemination of the mcr-1 colistin resistance gene. Lancet Infectious Diseases 16(2):147. doi: 10.1016/S1473-3099(15)00540-X

Onzivu W (2006) International environmental law, the public's health, and domestic environmental governance in developing countries. American University International Law Review 21(4): 597684.

Overgaard HJ, Suwonkerd W, Jeffrey Hii J (2015) The Malaria Landscape: Mosquitoes, Transmission, Landscape, Insecticide Resistance, and Integrated Control in Thailand. In: Morand S, Dujardin J-P, Lefait-Rollin R, Apiwathnasorn C (eds) Socio-ecological dimensions of Infectious Diseases in Southeast Asia. Springer Singapore, p 123-153 
Pilosof S, Morand S, Krasnov BR, Nunn CL (2015) Potential parasite transmission in multihost networks based on parasite sharing. PLoS One 10: e0117909

Ribas A, Jollivet C, Morand S, Thongmalayvong B, Somphavong S, Siew CC, Ting PJ, Suputtamongkol S, Saensombath V, Sanguankiat S, Tan BH, Paboriboune P, Akkhavong K, Chaisiri K (2017) Intestinal parasitic infection and environmental water contamination in a rural village of Northern Lao PDR: Identification of infection risk. Korean Journal of Parasitology 55(5):523-532. doi: 10.3347/kjp.2017.55.5.523

Ribolzi O, Rochelle-Newall E, Dittrich S, Auda Y, Newton PN, Rattanavong S,Knappik M, Soulileuth B, Sengtaheuanghoung O, Dance DB, Pierret A (2016) Land use and soil type determine the presence of the pathogen Burkholderia pseudomallei in tropical rivers. Environmental Sci Poll Res 23(8):7828-39. doi: 10.1007/s11356-015-5943-z

Salam A, Nogushi T, Pothitan R (2006) Community forest management in Thailand: current situation and dynamics in the context of sustainable development. New Forests 31(2):273-291. https://doi.org/10.1007/s11056-005-7483-8

Sibertin-Blanc C, Therond O, Monteil C, Mazzega P (2018) The entity-process framework for integrated agent-based modeling of social-ecological systems. This volume, chap. 5

Spierenburg M (2012) Getting the message across biodiversity science and policy interfaces - A review. GAIA 21(2):125 -134. https://doi.org/10.14512/gaia.21.2.11

SBSTTA (2017) Scenarios for The 2050 Vision For Biodiversity, Note by the Executive Secretary, Subsidiary Body on Scientific, Technical and Technological Advice CBD/SBSTTA/21/2, 15 September 2017.

Turgut NY (2008) The influence of ecology on environmental law: challenges to the concepts of traditional law. Environmental Law Review 10(2): 112-130. https://doi.org/10.1350/enlr.2008.10.2.012

United Nations Development Programme, United Nations Environment Programme, Government of Thailand (2010) Poverty/environment initiative framework in Thailand. Project document, strengthening inclusive and economic decision making for environmentally sustainable pro-poor development. UNDP, Bangkok, 29 p.

United Nations Development Programme Thailand (2014) Country brief, strengthening the governance of climate change finance in Thailand. UNDP, Bangkok, $14 \mathrm{p}$.

United Nations Environment Programme (UN Environment) (2015) The United Nations Environment Programme and the 2030 Agenda: Global Action for People and the Planet. UNEP, Nairobi, 8 p.

Van Panhuis WG, Choisy M, Xiong X et al. (2015) Region-wide synchrony and traveling waves of dengue across eight countries in Southeast Asia. PNAS 112(42):13069-13074. https://doi.org/10.1073/pnas.1501375112

Von Schirnding Y, Onvizu W, Adede AO (2002) International environmental law and global public health. Bulletin of the World Health Organization 80:970-74.

Wilcove DS, Giam X, Edwards DP, Flisher B, Koh LP (2013) Navjot's nightmare revisited: logging, agriculture, and biodiversity in Southeast Asia. Trends Ecology \& Evolution 28(9):531-40. doi: $10.1016 / j$.tree.2013.04.005

World Bank (2009) Strategic Environmental Assessment in East and Southeast Asia. A progress review and comparison of Country Systems and Cases. Dusik J., Xie J. (authors), World Bank's Technical Assistance Program "Developing Practice and Capacity of Strategic Environmental Assessments in East Asia and Pacific Region”, 69 p. Available from http://siteresources.worldbank.org/INTEAPREGTOPENVIRONMENT/Resources/SEAprogressrev iewinEAPFINAL.pdf Accessed 25 Feb 2018 